\title{
ANGKA KEJADIAN FLEBITIS DAN TINGKAT KEPARAHANNYA DI RUANG PENYAKIT DALAM DI SEBUAH RUMAH SAKIT DI JAKARTA
}

\author{
Hening Pujasari*, Made Sumarwati**
}

\begin{abstract}
Abstrak
Penelitian ini bertujuan untuk mengidentifikasi angka kejadian flebitis di ruang rawat penyakit dalam di Rumah Sakit di Jakarta, mengetahui waktu rata-rata terjadinya flebitis, dan tingkat keparahannya ketika flebitis tersebut diidentifikasi. Sebanyak 109 pasien yang mendapat terapi cairan intravena diobservas pada penelitian ini. Parameter yang digunakan adalah cairan intravena yang digunakan, tempat pemasangan kanul, waktu pemasangan dan waktu flebitis diidentifikasi. Hasil menunjukkan bahwa ditemukan 11 kasus flebitis, dengan rata-rata kejadian 2 hari setelah pemasangan, area pemasangan di vena metacarpal, dan jenis cairan yang digunakan adalah kombinasi antara Ringer Laktat dan Dekstrosa 5\%.
\end{abstract}

Kata kunci: Intravena, pemasangan kanul, vena metacarpal, Ringer laktat, Dekstrosa

\begin{abstract}
The objective of this research is to identify the number of phlebitis cases at an Internal Surgical of a Hospital in Jakarta and to describe the equal of time phlebitis including its grade when it is found. There were 109 clients who have intravenous therapy be observed in this research. Intravenous fluid, the area of canula insertion, the period of therapy, and the time of phlebitis, are used as parameters. It is shown that 11 of phlebitis cases are occurred, the equal of time is around the second day after insertion, the punctured area is metacarpal venous, and the intarvenous fluid is a combination of Ringer Lactate and 5\% Dextrose.
\end{abstract}

Key word: Intravenous, canula insertion, metacarpal venous, Ringer lactate, Dextrose. 